\author{
제주흑우 동결정액 제조 시 Amide 계열의 동결보호제가 동결 융해 후 정자의 \\ 성상에 미치는 영향 \\ 오신애 ${ }^{1} \cdot$ 최선호 $^{1} \cdot$ 고민희 $^{1} \cdot$ 강태영 $^{1} \cdot$ 조상래 $^{1} \cdot$ 고문석 $^{1} \cdot$ 오영미 $^{2} \cdot$ 조원모 $^{1 *}$ \\ 1농촌진흥청 국립축산과학원 난지축산시험장, ${ }^{2}$ 국립제주대학교 수의과대학
}

\title{
Effect of Amides as a Cryoprotectant on Quality of Frozen-thawed Sperm in Korean Jeju Black Bull
}

\author{
Shin-Ae Oh ${ }^{1}$, Sun-Ho Choi ${ }^{1}$, Min-Hee Ko ${ }^{1}$, Tae-Young Kang ${ }^{1}$, Sang-Rae Cho ${ }^{1}$, Moon-Suck Ko ${ }^{1}$, Young-mi Oh ${ }^{2}$ \\ and Won-Mo Cho ${ }^{1}$. \\ ${ }^{1}$ Subtropical Animal Experiment Station, National Institute of Animal Science, RDA, JeJu 690-150, Korea, \\ ${ }^{2}$ Department of Veterinary Medicine, Jeju National University, 690-756, Korea
}

\begin{abstract}
The objective of this study was to examine the effect of amides as a cryoprotectant for semen cryopreservation in Korean Jeju Black Bull. The semen was cryopreserved with extenders containing 5\% dimethyl acetamide (DMA), 5\% dimethyl formamide (DMF), 5\% methyl formamide (MF) or 7\% glycerol. Post-thawed sperm were evaluated for sperm motility, viability, acrosome integrity and membrane integrity. Post-thawed sperm motility was significantly higher $(\mathrm{p}<0.05)$ in glycerol and $\mathrm{DMF}(64.00 \% \pm$ 9.62 and $59.00 \% \pm 5.48$, respectively) than DMA and $\operatorname{MF}(50.00 \% \pm 3.24$ and $44.00 \% \pm 4.18$, respectively). Sperm viability wassignificantly higher $(\mathrm{p}<0.05)$ in glycerol and $\mathrm{DMF}(58.25 \% \pm 7.35$ and $53.05 \% \pm 3.77$, respectively $)$ than others. However, for sperm motility and viability, there were no differences among glycerol and DMF. Also, swelling sperm ratio by hypo-osmetic selling test $($ HOST $)$ was significantly increased $(\mathrm{p}<0.05)$ in glycerol and DMF treatments $(45.12 \% \pm 25.08$ and $44.95 \% \pm 8.58$, respectively). The percentage of capacitated sperm assessed by CTC staining, F pattern was lower $(\mathrm{p}<0.05)$ in DMF than others. B pattern was increased $(\mathrm{p}<0.05)$ in DMA, DMF and MF when compared with glycerol. AR pattern ratio was decreased $(\mathrm{p}<0.05)$ in glycerol and DMF when compared with DMA and MF. These results suggested that amides performed better and could be used as a cryoprotectant for semen freezing of Korean Jeju Black Bull.
\end{abstract}

(Key words : Korean Jeju Black Bull, Semen freezing, Cryoprotectants, Amide compound)

\section{서 론}

제주흑우는 $\mathrm{FAO}$ 에 등록되어 있는 한우 품종중 하나로 칡소 등 과 함께 멸실 위험에 처한 희소한우로 분류되어 있다. 제주흑우는 희소 품종으로 분류되어 있기에 현재 산업적 이용에 있어 활발한 유통은 어렵지만 국내 가축유전자원의 다양성 확보에 있어 매우 중 요한 국가적 자원이다. 또한 최근 국내의 한우 산업이 한미 자유무 역협정 (FTA) 체결과 같은 개방화의 진전으로 인해 경쟁력이 심화 되고 있으며, 그로인해 국내산 쇠고기의 가격은 주 수입국인 미국 에 비하여 4 배 이상 비싸 가격 경쟁력이 미약한 실정이다. 또한 국 민 소득이 증가함에 따라 육류의 소비가 증가되고 있을 뿐 아니라,
고급육에 대한 수요가 증가하고 있다. 따라서 국민의 기호 충족 뿐 아니라 외국산 쇠고기와의 경쟁력을 가질 수 있는 고유 한우의 품 종개발과 특성화 및 브랜드화가 필요하다. 따라서 이러한 일련의 목적을 위하여 제주흑우의 증식을 위한 수단으로 정액의 생산과 보 급이 지속적으로 이루어져야 한다. 그러나 현재 제주흑우의 정액의 채취와 동결 보존에 대한 연구는 매우 미흡한 실정이며, 최적 조건 을 확립하는 것은 매우 까다로운 일이다. 특히 정액의 동결에 있어 동결보호제의 역할은 동결의 성공여부를 가르는 문제라 할 만큼 중 요한 물질이다.

Glycerol은 침투성 동결보호제로 소를 포함한 다양한 포유동물 의 정자를 동결하는데 널리 이용되고 있다(Baren 등, 2004; Li

본 연구는 2011년도 농촌진흥청 국립축산과학원 박사후연수과정 지원사업에 의해 이루어진 것임

* Corresponding author: Won-Mo Cho, Subtropical Animal Experiment Station, National Institute of Animal Science, RDA, Odeung-dong San 175-6, Jeju-Do, 690-150, Korea. Tel: (064) 754-5716, Fax: (064) 754-5713, E-mail: cwmo3451@rda.go.kr 
등, 2006; Silva 등, 2002). Glycerol의 역할은 동결 융해 후 세포 가 받는 손상을 감소시키는 것으로, glycerol과 같은 침투성 동결 보호제(Mederios 등, 2002) 뿐만 아니라 비 침투성 동결보호제 (Breddermann과 Foot, 1969) 모두 같은 역할을 하는데 그 목적을 가지고 있다. Glycerol은 포유류의 정자를 동결함에 있어 그 사용 농도, 화학적 그리고 삼투압 독성에 관련하여 그것들이 정자의 세 포막과 대사작용에 영향을 미쳐 정자의 운동성과 수정능력을 감소 시키는 것에 대하여 비교적 잘 알려져 있다(Hammerstedt 등, 1990). 게다가 고농도의 Glycerol은 세포의 사멸을 야기시키며 (Wundrich 등, 2006), 침투성 동결보호제가 세포막을 통과하여 침 투할 때 침투 속도가 물의 속도보다 느리며, 이와 같은 이유로 동 결보호제를 제거할 때 물의 침투속도 보다 동결보호제가 제거되는 속도가 늦으므로 세포의 용적이 급격히 팽창되기 때문에 정자의 막 이 손상을 입어 동결보호제로 인한 삼투압 손상을 입게 된다고 보 고하였다 (Gao 등, 1995). Buranaamnuay 등 (2011)은 침투성 동 결보호제인 glycerol을 사용하여 동결된 대부분의 정자는 동결 융 해시 이와 같은 정자막의 손상이 정자의 질적인 저하와 수정능력이 떨어지는 이유라고 보고 하였다. 따라서 보다 높은 quality와 수정 능력을 가진 동결정액을 생산하기 위해서는 glycerol보다 침투성이 강하고, 분자량이 작아 동결 융해 과정동안 세포막에 손상을 적게 줄 수 있는 동결보호제가 필요하다. Amide 계열의 동결보호제는 glycerol에 비하여 분자량이 작고, 침투성이 높아 세포내 삼투압 손상을 최소화 할 수 있어 정자의 운동성 및 수정능력의 감소가 낮 아진다고 보고된 바 있으며, 말의 동결정액 제조시 이들 amide 계 열 동결보호제의 이용은 glycerol을 사용하였을 때보다 정자의 운 동성 및 수정능력이 개선되었음을 보고 하였다 (Alverenga 등, 2005).

따라서 본 연구는 amide 계열의 동결보호제로서 dimethyl acetamide (DMA)와 dimethyl formamide (DMF) 그리고 methyl formamide $(\mathrm{MF})$ 를 사용하여 제주흑우 정액의 동결 융해 후 정자 의 성상에 미치는 영향을 조사하고자 실시하였다.

\section{재료 및 방법}

\section{1. 제주흑우 정액 채취}

정액채취에 이용된 흑우는 3세 이상의 수컷 6 두를 선발하여 별 도 공간에서 자유 급식하여 사육하였으며, 월 4회 정액을 채취하였 다. 정액 채취는 인공질 (Model 66000-D, Nasco, FHK, 일본)을 사용하여 채정하였다. 정액 채취를 위하여 암컷을 안전하게 정액 채취실 보정틀에 고정시킨 후, 제주흑우 수컷을 2 3회 암컷의 주 위를 맴돌게 하여 흥분을 유도하였다. 승가가 이루어지면 수컷의 penis를 인공질에 삽입하여 정액을 채취하였다. 인공질의 온도는 $38^{\circ} \mathrm{C}$ 를 유지하였으며, 인공질에는 penis의 삽입을 원활하게 하기 위하여 젤을 도포하였다. 인공질 끝 부분에 $15 \mathrm{ml}$ tube를 채취 전 에 장착하여 사출된 정액을 회수하였다. 회수된 정액은 $37^{\circ} \mathrm{C}$ 온장
고에 넣어 신속하게 실험실로 이동하였다.

\section{2. 정액의 처리 및 제조}

본 실험에 이용된 보존액의 조성은 Table 1 과 같으며, 동결보호 제로 $7 \%$ 의 Glycerol과 $5 \%$ 의 $\mathrm{DMA}, \mathrm{DMF}$ 그리고 $\mathrm{MF}$ 를 이용하 였다. 채취된 정액은 즉시 실험실로 운반하고, 원정액을 Tris-Egg yolk extender와 1:1로 희석하여 냉각을 시작하여 5단계를 거쳐 총 2 시간동안 냉각시켰다. 마지막 희석 후, 동결보호제가 첨가된 희석액을 첨가하여 2 시간동안 평형을 유도하였으며, 평형이 완료된 정자는 $50 \times 10^{6} / \mathrm{ml}$ 로 농도를 조절하여 $0.5 \mathrm{ml} \mathrm{straw}$ 에 충전 봉합하 였다. 충전된 straw는 액체질소 표면 $5 \mathrm{~cm}$ 높이에서 10 분간 노출 시켜 예비동결을 실시한 후에 액체질소에 침지하여 동결을 완료하 였다. 동결된 정액은 $\mathrm{LN}_{2}$ tank에서 보관하여 최소 1주일 이상 보 존 후 필요 시 융해하여 사용하였다. 동결정액의 융해는 공기중에 서 약 10 초간 노출한 후 $37^{\circ} \mathrm{C}$ 온수에 20 초간 침지시켜 융해하여 정자의 생존율 및 정자 양상을 조사하였다.

Table 1. Composition of Tris-egg yolk extender

\begin{tabular}{cc}
\hline Component & Concentration \\
\hline \hline Tris & $121.1 \mathrm{mM}$ \\
Fructose & $180.2 \mathrm{mM}$ \\
Citric acid & $294.1 \mathrm{mM}$ \\
Egg yolk & $10 \%$ \\
Glycerol/ DMA, DMF, MF & $7 \% / 5 \%$ \\
Streptomycin sulfate & $10 \mathrm{mg} / \mathrm{ml}$ \\
\hline
\end{tabular}

\section{3. 정자의 운동성 평가}

MicroLux 현미경 (X 70, Olympus, Japan)하에서 정자의 운동 성을 평가하였다. 혈구계산판에 $5 \mu \mathrm{l}$ 의 정액을 놓고 cover glass로 덮은 후 100 배율에서 정자의 운동성을 육안 평가하였다. 혈구계산 판의 격자 2 군데를 반복적으로 관찰하여 거의 모든 정자들이 소용 돌이 치며 활발하게 움직이는 것을 $90 \%$ 이상으로, 생존 정자들을 격자 별로 100 개 가량을 관찰하여 활발하게 움직이는 정자들이 80 개 이상일 때 $80 \%$ 로, 70 개 이상일 때 $70 \%$ 로 판단하고 움직이는 정도가 전진 운동 또는 느리게 전진 운동하는 수준일 때 $50 \%$, 느 리게 전진운동하거나 진자 운동 혹은 미동하는 수준일 때 $30 \%$ 로 평가하였다.

\section{4. 정자의 생존율 평가}

정자의 생존율은 Eosin-Y 염색법을 이용하여 생존율을 평가하였 다. $0.9 \% \mathrm{NaCl}$ 용액에 $0.5 \%$ Eosin-Y를 용해한 후 $10 \mu \mathrm{l}$ 의 정액 
을 slide glass 위에 올린 다음 동량의 염색액을 섞어 도말한 다음 cover glass를 덮고 MicroLux 현미경 (X 70, Olympus, Japan)하 에서 관찰하였다. 100 배율에서 염색 상태를 관찰하여 표본 1 개당 200 개의 정자를 카운트하여 붉게 염색된 죽은 정자의 비율을 계산 하였으며, 개체 당 2 개의 표본을 만들어 총 400 개의 정자를 카운 트하여 생존율을 평가하였다.

\section{5. 정자막 온전성 평가}

정자막 온전성을 측정하기 위하여 Jeyendran 등 (1984)의 방법 을 변형하여 저삼투압 용액을 이용한 정자 미부의 팽창형태를 분석 하였다(Hypo-Osmetic Swelling Test: HOST). $37^{\circ} \mathrm{C}$ 의 저장액 $(150 \mathrm{mOsm} / \mathrm{kg}, 0.45 \% \mathrm{NaCl}$ 용액) $1 \mathrm{ml}$ 에 정자 샘플 $100 \mu \mathrm{l}$ 를 혼합하여 $37^{\circ} \mathrm{C}$ 에서 5 분간 정치시킨 후 슬라이드 글라스에 도말하 여 개체당 2 개의 slide 표본을 만들어 표본당 200 개의 정자를 카 운트하여 정자막의 온전성을 평가하였다.

\section{6. 첨체막 변화 양상의 측정}

첨체막의 변화 양상을 측정하기 위하여 Chlortetracyclin (CTC) 염색법을 사용하였으며, 이 방법으로 정자의 수정능획득과 첨체막 변화 양상을 조사하였다. 정액을 $400 \mathrm{Xg}$ 에서 2분간 원심분리하여 세척한 다음 $500 \mu \mathrm{l}$ 의 CTC 용액 $(750 \mu \mathrm{M} \mathrm{CTC}, 130 \mathrm{mM} \mathrm{NaCl}$, $5 \mathrm{mM}$ cystein in $20 \mathrm{mM}$ Tris buffer; $\mathrm{pH}$ 7.8)을 혼합하여 20초 간 암실에서 상온배양 하였다. CTC 반응을 고정시키기 위하여 10 $\mu \mathrm{l}$ 의 $12.5 \%$ glutaradehyde를 혼합하여 $4{ }^{\circ} \mathrm{C}$ 에서 보관하였다. 염색 후 24시간 이내에 판독하였으며, 정자 첨체막 양상은 Fraser (1995)의 판독 기준에 따라 정자 두부가 전체적으로 형광색을 발 할 경우 수정능획득이 일어나지 않은 $\mathrm{F}$ pattern으로, 적도면 부분 에 띠가 형성되어 첨체 아랫부분에서 형광색을 발할 경우 수정능획 득이 일어난 B pattern으로 구분하였으며, 마지막으로 정자 두부가 형광색을 발하지 않거나, 산만한 발광을 할 경우 첨체반응이 일어 난 AR (acrosome reaction) pattern으로 구분하였다.

\section{7. 통계 분석}

통계 분석은 통계분석프로그램(SPSS version 18.0)을 이용하 였으며, 동결보호제에 따른 동결 융해 후 정자의 활력과 생존율 그 리고 첨체와 정자막 양상변화에 대한 결과는 ANOVA를 이용하여 유의성 $(\mathrm{p}<0.05)$ 을 검증하였다.

\section{결 과}

1. Amide 계열의 동결보호제가 동결 융해 후 정자의 운동성 및 생존율에 미치는 영향
제주흑우 정액의 동결제조시 amide 계열의 동결보호제를 이용하 여 동결 보존 후 융해하였을 때 정자의 운동성 및 생존율에 관한 결과는 Table 2와 같다. DMF가 amide 계열의 동결보호제 중에 유의적으로 가장 높은 정자의 운동성과 생존율을 나타내었으며 $(\mathrm{p}<0.05)$, glycerol에 비하여는 $\mathrm{DMF}$ 의 처리는 다소 낮은 운동성 과 생존율의 결과를 보였으나 유의적 차이는 볼 수 없었다.

Table 2. Comparing amides cryoprotectants with glycerol for semen cryopreservation of Korean Jeju Black Bull

\begin{tabular}{ccc}
\hline & Motility (\%) & Viability (\%) \\
\hline \hline Ejaculated sperm & $86 \pm 9.62$ & $82.15 \pm 7.35$ \\
\hline Glycerol & $64 \pm 9.62^{\mathrm{a}}$ & $58.25 \pm 6.63^{\mathrm{a}}$ \\
DMA & $50 \pm 3.24^{\mathrm{b}}$ & $30.7 \pm 2.35^{\mathrm{b}}$ \\
DMF & $59 \pm 5.48^{\mathrm{a}}$ & $53.05 \pm 3.77^{\mathrm{a}}$ \\
MF & $44 \pm 4.18^{\mathrm{b}}$ & $26.3 \pm 5.87^{\mathrm{b}}$ \\
\hline
\end{tabular}

${ }_{\mathrm{a}, \mathrm{b}}$ Values with different superscripts within column except ejaculated sperm are significantly different by ANOVA $(\mathrm{p}<0.05)$.

Data are presented as mean $\pm \mathrm{SD}$.

2. Amide 계열의 동결보호제가 정자막 온전성에 미치 는 영향

Table 3은 제주흑우 정액을 amide 계열의 동결보호제를 이용하 여 동결 보존하였을 때 동결 융해 후 정자막 온전성의 변화에 대한 결과이다. 운동성 및 생존율의 경우와 마찬가지로 amide 계열의 동결보호제에서는 $\mathrm{DMF}$ 의 처리구에서 유의적으로 높은 swelling sperm의 비율을 볼 수 있다 $(\mathrm{p}<0.05)$. Glycerol의 처리구에서 $\mathrm{DMF}$ 처리구보다 다소 높은 swelling sperm의 비율을 나타내었으 나 이들 처리구간의 유의적 차이는 나타나지 않았다.

Table 3. Effect of amides cryoprotectants on sperm membrane integrity of post-thawed Korean Jeju Black Bull spermatozoa

\begin{tabular}{cc}
\hline & Swelled sperm (\%) \\
\hline \hline Ejaculated sperm & $67.7 \pm 13.62$ \\
\hline Glycerol & $45.12 \pm 5.08^{\mathrm{a}}$ \\
DMA & $28.25 \pm 2.39^{\mathrm{b}}$ \\
DMF & $44.95 \pm 8.58^{\mathrm{a}}$ \\
MF & $19.75 \pm 6.60^{\mathrm{b}}$ \\
\hline
\end{tabular}

${ }^{\mathrm{a}, \mathrm{b}}$ Values with different superscripts within column except ejaculated sperm are significantly different by ANOVA $(p<0.05)$.

Data are presented as mean $\pm \mathrm{SD}$. 
3. Amide 계열의 동결보호제가 정자의 첨체막 양상의 변화에 미치는 영향

제주흑우 정액을 Amide 계열의 동결보호제를 이용하여 동결 융해 후 정자의 수정능획득 양상의 변화를 관찰한 결과는 Fig. 1 과 같 다. F pattern에 있어서 $\mathrm{MF}$ 를 제외한 모든 실험구에서 유의적 차 이를 볼 수 없었다. B pattern의 비율은 amide 계열의 동결 보호 제를 처리하였을 때 glycerol에 비하여 유의적으로 증가하는 결과 를 볼 수 있었다 $(\mathrm{p}<0.05)$. 그러나 $\mathrm{AR}$ pattern에 있어 $\mathrm{DMF}$ 와 glycerl이 유의적으로 낮은 비율의 AR pattern을 나타내었으나 $(\mathrm{p}<0.05), \mathrm{DMF}$ 와 glycerol간의 유의적 차이는 나타나지 않았다.

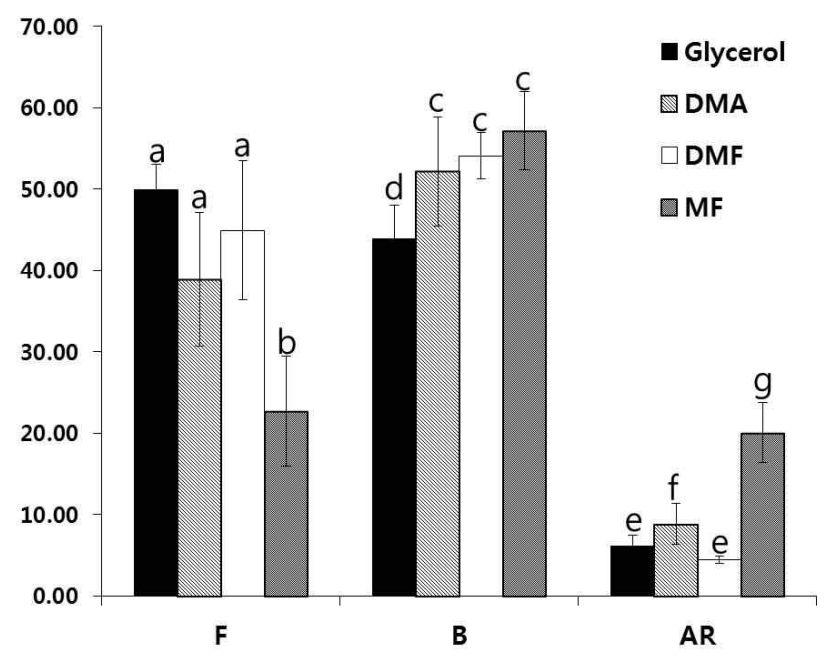

Fig. 1. Change of sperm capacitation status according to different croyprotectants.

${ }^{\mathrm{a}, \mathrm{b}} \mathrm{F}$ pattern values for various cryoprotectants with different superscripts were significantly different by ANOVA $(\mathrm{p}<0.05)$.

${ }^{c, d} \mathrm{~B}$ pattern values for various cryoprotectants with different superscripts were significantly different by ANOVA $(\mathrm{p}<0.05)$.

${ }^{e, f, g}$ AR pattern values for various cryoprotectants with different superscripts were significantly different by ANOVA $(p<0.05)$.

4. DMF가 동결 융해 후 시간에 따른 정자 생존율 및 정자막 온전성에 미치는 영향

$\mathrm{DMF}$ 를 처리하여 동결 보존한 제주흑우의 정자를 동결 융해하였 을 때 시간에 따른 정자의 생존율 및 정자막 온전성의 감소를 나타 낸 결과는 Fig. 2 와 같다. $\mathrm{DMF}$ 를 처리한 정자가 시간에 따라 감 소하는 생존율을 glycerol 처리구와 비교하였을 때(A), DMF 처리 구에서 1시간을 기점으로 시간이 흐름에 따라 glycerol 처리구보다 높은 생존율을 나타냈으며, 또한 정자막 온전성에 있어서도(B) swelling sperm의 비율이 생존율과 마찬가지로 1 시간 이후부터 $\mathrm{DMF}$ 처리구에서 보다 높게 나타났으나 이들의 차이에서 유의적 차이는 볼 수 없었다.

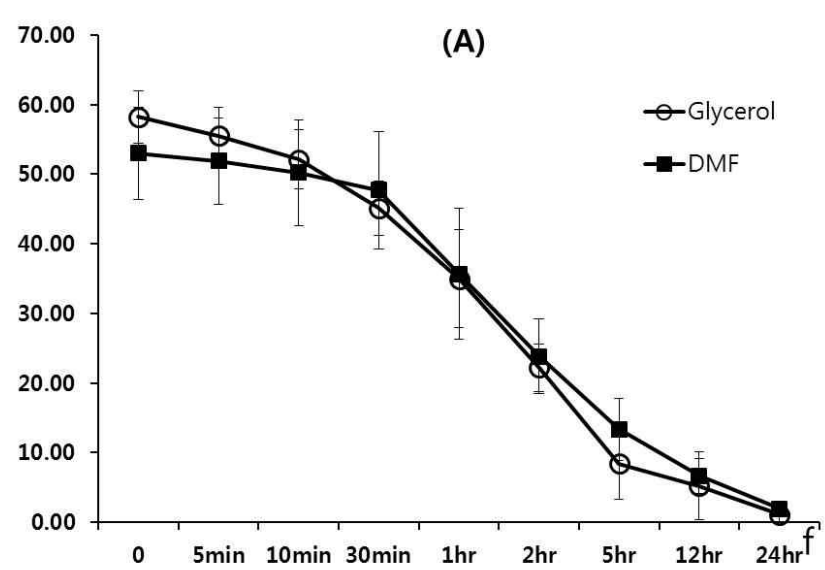

(B)

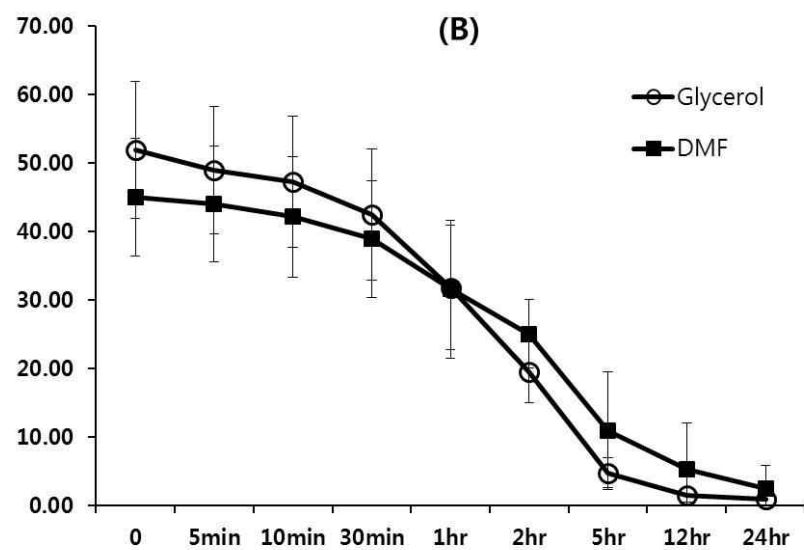

Fig. 2. Effect of DMF on changes over time in sperm viability $(A)$ and sperm membrane integrity $(B)$ at $37^{\circ} \mathrm{C}$

\section{고 찰}

본 연구는 분자량이 glycerol 보다 작은 amide 계열의 동결보호 제를 제주흑우 정액의 동결에 이용하여 동결 융해 후 정자의 성상 변화를 확인하여 새로운 동결보호제로서의 이용 가능성을 조사하고 자 실시하였다. 본 실험의 결과 제주흑우의 동결 융해 후 정자의 운동성 및 생존율은 DMF 처리구에서 glycerol 보다 다소 낮은 결 과를 보였으나 통계적 유의성은 입증되지 않았다. 이러한 결과는 돼지 (Bianchi 등, 2008), 말 (Squires 등, 2004; Medeiros 등, 2002; Vidament 등, 2002), 설치류 (Tselutin 등, 1999)의 동결정 액 제조에 있어 DMF가 효과적인 동결보호제로 사용되었음이 보고 된 바와 같이 제주흑우의 동결정액 제조에 있어서도 성공적으로 glycerol을 대체할 수 있는 물질이라고 평가된다. 비록 glycerol과 amide 계열의 동결보호제가 동결 과정 동안에 정자세포를 보호하 는 동일한 역할을 하지만, 각기 동결보호제들은 서로 다른 기작으 로 동결보호제로서의 역할을 수행한다. Glycerol의 hydroxyl radical은 그들 스스로가 결합하여 물 분자들의 결합을 감소시키는 
역할을 하여 용액의 밀도를 높이는 바람직하지 못한 현상을 초래 (Karow, 2001)하고 세포내 화학적 독성을 유발하여 세포 손상을 일으키게 된다(Almilid 등, 1988; Holt, 2000; Watson, 2000). 반면에 amide 계열의 동결보호제는 nitrogen을 포함하며, 이들의 nitrogen은 물 분자내의 hydrogen과 결합함으로써 amide와 물 사 이의 상호작용을 가지게 된다(Bianchi 등, 2008). 특히 amide 분 자안의 methyl기가 융합함으로 인하여 강한 소수성의 특징 갖게 되는데 이로 인해 amide가 정자막 내로 침투하는 능력이 증가된다 고 하였다(Bianchi 등, 2002). 또한 glycerol에 비하여 amide의 낮은 분자량과 낮은 밀도는 osmotic stress를 감소시켜 세포의 손 상을 감소시킬 수 있다(Ball과 Vo, 2001). 이러한 사실은 본 실 험에서 glycerol 처리구와 DMA 처리구간의 운동성 및 생존율을 비교하였을 때(Table 1), DMF 처리구에서 glycerol의 처리구에 비하여 운동성이 약 $14 \%$ 정도가 낮았으나 생존율은 약 $5 \%$ 정도 의 차이를 보인 것과 같은 결과를 설명할 수 있다. 따라서 본 실험 의 결과는 DMF가 glycerol에 비교하였을 때 낮은 농도로도 충분 히 세포내 침투를 하여 성공적인 동결이 가능한 것으로 평가된다.

Bianchi 등 (2002)은 돼지 정액의 동결정액 제조시 5\%의 DMA 와 $\mathrm{DMF}$ 를 처리하였을 때 가장 높은 수준의 정자막 온전성을 보 고한 바 있다. 그러나 본 연구의 결과 $\mathrm{DMF}$ 를 처리한 실험구에서 $\mathrm{DMA}$ 와 $\mathrm{MF}$ 를 처리한 실험구보다 유의적으로 $(\mathrm{P}<0.05)$ 높은 정자 막 온전성을 보고하고 있다(Table 3 ). 이러한 정자막 온전성 검사 는 정자의 대사 뿐만 아니라 난자와의 수정 및 정자의 수정능획득 과 첨체 반응과도 밀접한 관계가 있어 정자의 수정능을 평가하는데 유용한 지표로 사용되고 있다(Jeyendran 등, 1984). 이러한 검사 는 직접적으로 인공수정을 시행하거나, 체외수정방법을 통한 검사 를 수행하는 것 보다 시간과 비용적인 면에서 절약할 수 있으며 손 쉽게 수정능력을 예측할 수 있다. 특히 사람에서 수정 또는 가임능 력을 평가하기 위하여 정자막 온전성을 검사, 저장액에서 정자 미 부의 팽창 패턴을 평가하여 그 수정능력을 예측하고 있다(최 등, 1993). 본 연구의 결과 $\mathrm{DMF}$ 를 처리한 실험구와 glycerol을 처리 한 실험구에서 $\mathrm{DMF}$ 가 다소 낮은 수준의 정자 팽창 비율을 나타 내고 있지만 유의적인 차이는 나타나지 않았다 (Table 3). 이는 DMF가 glycerol 수준의 동결보호제로서의 역할을 수행하고 있음 을 시사한다.

일반적으로 정자의 동결 융해 후 성상 평가에 있어 운동성, 생존 율 및 정자막 온전성 뿐만 아니라 수정능획득 또는 첨체반응 또한 매우 중요하다. 정자의 수정능획득 또는 첨체반응은 정자의 수정능 력과 밀접한 관련이 있음이 보고된 바 있다(Kommisrud, 2002). 또한 $\mathrm{Oh}$ 등 (2010)은 돼지 정자에서 CTC 염색법을 이용한 정자 의 수정능획득 및 첨체반응의 평가는 번식성적이 불량한 개체를 예 측하는데 매우 유용하다고 보고한 바 있다. 사출직후 정자는 $\mathrm{F}$ pattern의 비율이 높아야 하며, 수정전 정자는 $\mathrm{AR}$ pattern에 비하 여 B pattenr의 비율이 높아야 한다(Fraser, 1995). Suzuki 등 (2003)은 B pattern 정자와 인공수정시 수정능력 간에 직접적인 관계가 있어 이들의 비율이 정액의 질을 판단하는 척도로 사용될
수 있다고 보고하였다. 수정능획득이 완료된 정자는 투명대에 의해 첨체반응이 일어나지만(Yanagimach, 1994), 투명대와 결합 전 첨 체반응이 일어난 정자는 투명대와의 결합에 필요한 요소를 손실하 게 되므로 정상적인 수정에 참여할 수 없다(Adeoya-Oshiguwa 와 Fraser, 2004). 본 연구에서 동결 융해 후 CTC 염색을 통해 정자 의 수정능획득과 첨체반응을 관찰한 결과(Fig. 1), $\mathrm{AR}$ pattern의 비율에 있어 $\mathrm{DMF}$ 와 glycerol에서 유의적으로 낮은 비율의 $\mathrm{AR}$ pattern을 나타냈다 $(\mathrm{p}<0.05)$ 이러한 결과는 $\mathrm{DMF}$ 가 정자의 첨체 를 저온 충격에서 효과적으로 보호하고 있음을 알 수 있다. $\mathrm{B}$ pattern의 비율은 모든 실험구에서 비슷한 양상을 나타났으나, $\mathrm{DMF}$ 처리구에서 유의적으로 가장 높은 비율을 나타냈으며, amide 계열의 동결보호제가 glycerol 처리에 비교하여 유의적으로 높게 나타났다 $(\mathrm{p}<0.05)$. 이는 amide 계열의 동결보호제는 충분한 비율의 수정 가능한 정자를 성공적으로 보호할 수 있음을 시사한 다. 또한 DMF와 glycerol을 동결보호제로 이용 하였을 때, 시간이 경과함에 따라 정자의 생존율과 정자 미부의 팽창율의 차이가 크게 보이지 않았으며, 1 시간이 경과된 이후부터는 DMF 처리구에서 생 존율과 정자 미부의 팽창 비율의 감소가 glycerol 처리구보다 낮게 나타났다(Fig. 2). 이러한 결과는 amide 계열의 동결보호제인 $\mathrm{DMF}$ 가 정자를 성공적으로 보호하여 수정능력을 안정적으로 유지 하고 있음을 시사하며, 희소 한우 품종인 제주흑우의 안정적인 정 액 동결방법을 확립하는데 있어 효과적인 자료를 제시할 것으로 평 가된다.

\section{요 약}

본 연구는 희소 한우인 제주흑우의 정액 동결을 위하여 동결보호 제로서 glycerol과 amide 계열의 동결보호제인 5\%의 DMA, $\mathrm{DMF}$ 그리고 $7 \%$ 의 $\mathrm{MF}$ 를 이용하여 동결 융해 후 정자의 운동성, 생존율, 정자막 온전성 및 정자의 첨체 양상의 변화 조사를 위하여 수행하였다. 제주흑우의 정액을 동결 한 결과 glycerol과 $\mathrm{DMF}$ 를 사용하였을 때 운동성은 $64.00 \pm 9.62$ 와 $59.00 \pm 5.48$ 로 $\mathrm{DMA}$ 와 $\mathrm{MF}$ 에 비해 유의적으로 높았으며 $(\mathrm{p}<0.05)$, 생존율 역시 glycero과 $\mathrm{DMF}$ 처리구에서 $58.25 \pm 6.63$ 과 $53.05 \pm 3.77$ 로 유의적으로 높게 나타났다 $(\mathrm{p}<0.05)$. 그러나 glycerol과 $\mathrm{DMF}$ 처리구 간의 유의적 차이는 나타나지 않았다. 정자막 온전성 검사(HOST)에 있어서도 역시 glycerol과 DMF 처리에서 정자 미부의 팽창 비율 역시 $45.12 \pm 25.08$ 과 $44.95 \pm 8.58$ 로 유의적으로 높았다 $(\mathrm{p}<0.05)$. 정자 의 첨체막 양상 변화에 있어 $\mathrm{F}$ pattern의 비율이 $\mathrm{MF}$ 처리시 다른 처리구에 비하여 유의적으로 낮았으며 $(\mathrm{p}<0.05), \mathrm{B}$ pattern의 비율 은 $\mathrm{DMA}, \mathrm{DMF}$ 및 $\mathrm{MF}$ 의 사용시 glycerol에 비하여 유의적으로 증가하였다 $(\mathrm{p}<0.05)$. $\mathrm{AR}$ pattern의 비율에 있어서는 $\mathrm{DMF}$ 를 제외 한 amide의 사용은 $\mathrm{F}$ pattern의 감소와 조기 첨체반응에 의한 유 의적인 $\mathrm{AR}$ pattern의 증가를 볼 수 있었다 $(\mathrm{p}<0.0 .5)$. 그러나 $\mathrm{DMF}$ 의 사용은 glycerol 보다 AR pattern의 비율이 유의적으로 낮았다 $(\mathrm{p}<0.05)$. 동결 융해 후 시간에 따른 정자의 생존율과 정자 
미부 팽창 비율에 있어서 융해 초기에는 glycerol에서 $\mathrm{DMF}$ 보다 높은 생존율과 정자 미부 팽창율을 나타냈으나, 1 시간 이후부터는 $\mathrm{DMF}$ 에서 glycerol 보다 높은 생존율과 정자 미부 팽창율을 나타 내었다. 이러한 결과는 희소 가축의 생식세포 보존 및 유전자원 확 립을 위한 중요한 자료가 될 것이며, 제주흑우 및 희소 가축의 안 정적이고 효율적인 동결 정액 제조 연구에 있어 중요한 정보를 제 공할 것으로 평가된다.

(주제어: 제주흑우, 동결정액, 동결보호제, 아마이드 화합물)

\section{인 용 문 헌}

Adeoya-Osiguwa, S. A. and Fraser, L. R. 2004. Environmental estrogens and sperm function. Hum. Reprod. 19:216-217.

Alimilid, T. and Johnson, L. A. 1988. Effects of glycerol concentration, equilibration time and temperature of glyceril addition on post-thaw viability of boar spermatozoa frozen in straws. J. Anim. Sci. 66:2899-2905.

Alvarenga, M. A., Leao, K. M., Papa, F. O., Landim-Alvarenga, F. C. abd Medeiros, A. S. L. 2005. Amides as cryoprotectants for freezing stallion semen: a review. J. Anim. Reprod. 89:105-113.

Ball, B. A. and Vo. A. 2001. Osmotic tolerance of equine spermatozoa and the effects of soluble cryoprotectants on equine sperm motility, viabiliry and mithchonderial membrane potenrial. J. Androl. 22:1061-1069.

Baren, A., Bacinouglu, S., Evecen, M., Sahin, B. E., Alkan, S., Demir, K., Ak, K. and Ileri, K. 2004. Freezing of cat semen in straws with different GLY levels containing Tris-extender. Turk. J. Vet. Anim. Sci. 25:545-552.

Bianchi, I., Calderam, K., Maschio, E. F., Madeira, E. M., da Rosa Ulguim, R., Corcini, C. D., Bongalhardo, D. C., Correa, E. K., Lucia Jr., T., Deschamps, J. C. and Correa, M. N. 2008 Evaluation of amides and centrifugation temperature in boar semen cryopreservation. Theriogenology 69:632-638.

Breddermann, J. P. and Foot, R. H. 1969. Volume of stressed bull spermatozoa protoplasmic droplets, and the relation ship of cell size to motility and fertility. J. Dairy Sci. 28:496-501.

Buranaamnuay, K., Grossfeld, R., Struckmann, C. and Rath, D. 2011. Influence of cryoprotectants glycerol and amides, combined with antioxidants on quality of frozen-thawed boar sperm. Anim. Reprod. Sci. 127:56-61.

Dalimata, A. M. and Graham, J. K. 1997. Cryopreservation of rabbit spermatozoa using acetamide in combination with trehalose and methylcellulose. Theriogenology 49:831-841.

Fraser, L. R., Abeydeera, L. R. and Niwa, K. 1995. $\mathrm{Ca}^{2+}$-regulating mechanisms that modulate bull sperm capacitation and acrosomal exocytosis as determined by chlortetracycline analysis. Mol.
Reprod. Dev. 40:233-241.

Gao, D. Y., Liu, J., Liu, C., McGann, L. E., Watson, P. F., Kleinhans, F. W., Mazur, P, Critser, E. S. and Critser, J. K. 1995. Prevention of osmotic injury to human spermatozoa during addition and removal of glycerol. Hum. Reprod. 10:1109-1022.

Hammerstedt, R. H. and Graham, J. K. 1992. Cryopreservation of poultry semen: the enigma of GLY. Cryobiology 29:26-38.

Hammerstedt, R. H., Graham, J. K. and Nolan, J. P. 1990. Cryopreservation of mammalian sperm: what we ask them to survive. J. Androl. 11:73-88.

Holt, W. V. 2000. Basic aspects of frozen storage of semen. Anim. Reprod. Sci. 62:3-22.

Jeyendran, R. S., Van der Ven H. H., Perez-Pelaez, M. Carbo, B. G. and Zaneveld, L. J. 1984. Development of an assay to assess the functional integrity of the human sperm membrane and its relationship to other semen characteristics. J. Reprod. Fertil. 70:219-228

Karow. A. M. 2001. Cryobiology 2001 for mammalian embryologists. In: Embryology Pre-congress Course(Laser and Infertility/Freezing in Reproduction), Georgia, U.S.A., pp. 1-37.

Kommisrud, E., Paulenz, H., Sehested, E. and Greule, I. S. 2002. Influence of boar and semen parameters on motility and acrosome intefrity in liquid boar semen stored for 5 days. Acta. Veterinaria Scandinavia. 43:49-55.

Li, G., Saenz, J., Godke, R. A and Devireddy, R. V. 2006. Effect of GLY and cholesterol-loaded cyclodextrin on freezing-induced water loss in bovine spermatozoa. Reproduction 131:875-886.

Medeiros, C. M. O., Forell, F., Oliveira, A. T. D. and Rodrigues, J. L. 2002. Currebt status of sperm cryopreservation: Why isn't it better? Theriogenology 57:327-344.

Oh, S. A., Park, Y. J., You, Y. A., Mohamed, E. A. and Pang, M. G. 2010. Capacitation status of stored boar spermatozoa is related litter size of sows. Anim. Reprod. Sci. 121:131-138.

Silva, A. R., de Cassia Soares Cardoso, R., Uchoa, D. C. and MacHado da Silva, L. D. 2002. Effect of Tris-buffer, egg yolk and GLY on canine semen freezing. Vet. J. 164:244-246.

Squires, E. L., Keith, S. L. and Graham, J. K. 2004. Evaluation of alternative cryoprotectants for preserving stallion spermatozoa. Theriogenology 62:1056-1065.

Tselutin, K., Seigneurin, F. and Blesbois, E. 1999. Comparison of cryoprotectants and methods of cryopreservation of fowl spermatozoa. Poult. Sci. 78:586-90.

Vidament, M., Daire, C., Yvon, J. M. Doligez, P., Bruneau, B. Magistrini, M. and Ecot, P. Motility and fertility of stallion semen frozen with glycerol and/or dimethylformamide. Theriogenology 58:249-251. 
Watson, P. F. 2000. The causes of reduces fertility with cryopreserved semen. Anim. Reprod. Sci. 60:482-492.

Wundrich, K., Passch, U., Leicht, M. and Glander, H. J. 2006. Activation of caspases in human spermatozoa during cryopreservation-an immunoblot study. Cell Tissue bank 7:81-90.

Yanagimachi, R. 1994. Mammalian fertilization. In The Physiology of
Reproduction, E. Knobil and J. D., Neill (Ed), 2dn de., Raven Press., New York, U.S.A., pp. 189-317.

최두석, 문신용, 장윤석. 1993. 남성 불임검사 중 정자 형태와 정자 운동성 검사 및 저장성 용액 내 정자 팽창 검사의 상관관계 및 가임능력 예측 에 관한 연구. 대한산부인과학회잡지 36:2497-2509.

(Received Apr. 10, 2012; Revised Apr. 23, 2012; Accepted Apr. 23, 2012) 